\title{
数値計算による自己誘起磁場型アルゴン MPD スラスタの熱設計*1 Thermal Design of a Self-Field Argon MPD Thruster by Numerical Calculation
}

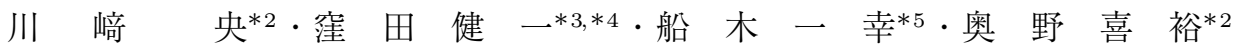

Akira Kawasaki, Kenichi Kubota, Ikkoh Funaki and Yoshihiro Okuno

Key Words : Electric Propulsion, MPD Thruster, Self Field, MHD Flow Analysis, Thermal Analysis, Design

\begin{abstract}
A 400-kW-class steady-state self-field magnetoplasmadynamic (MPD) thruster is numerically designed with a combination of magnetohydrodynamic (MHD) and thermal analyses, where a heat flux evaluated from the MHD analysis is imposed on the electrode as a boundary condition in the thermal analysis. The increase in the ratio of an anode radius to a cathode radius improves the thrust performance, but can rise the temperature locally at an anode downstream edge and a cathode tip due to the concentration of discharge current and/or insufficient heat removal. It is suggested, however, that a thruster without electrode melting is realizable even at such a high input power by setting an appropriate cathode radius and enhancing heat removal from the electrode by means of heat pipe. The thruster designed under the thermal constraint is expected to achieve a thrust of $17 \mathrm{~N}$, a specific impulse of $990 \mathrm{~s}$, a thrust efficiency of $21 \%$ for argon propellant.
\end{abstract}

\section{記号の説 明}

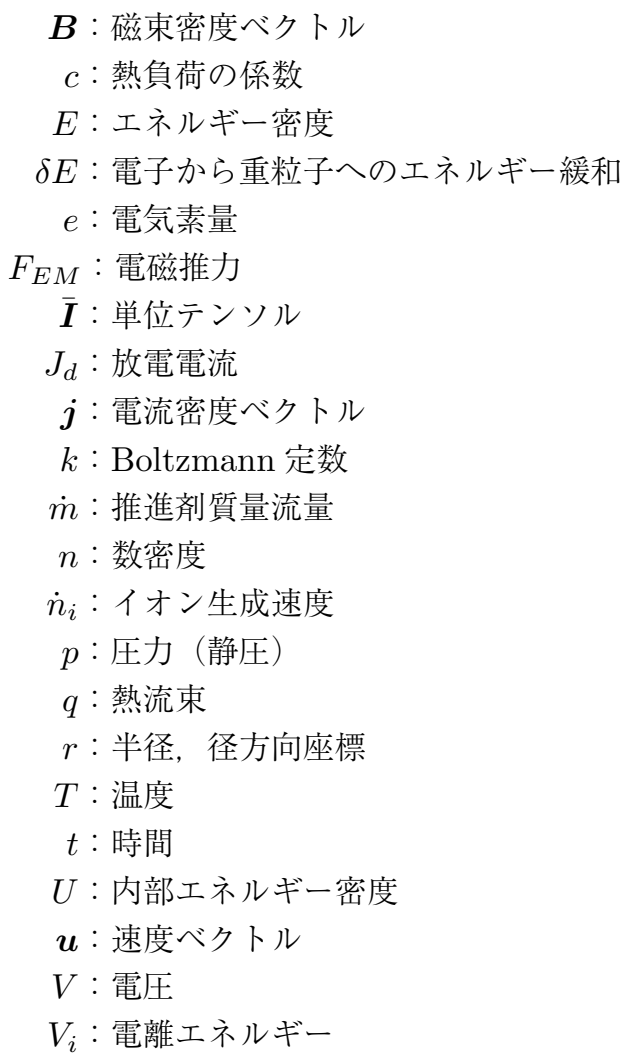

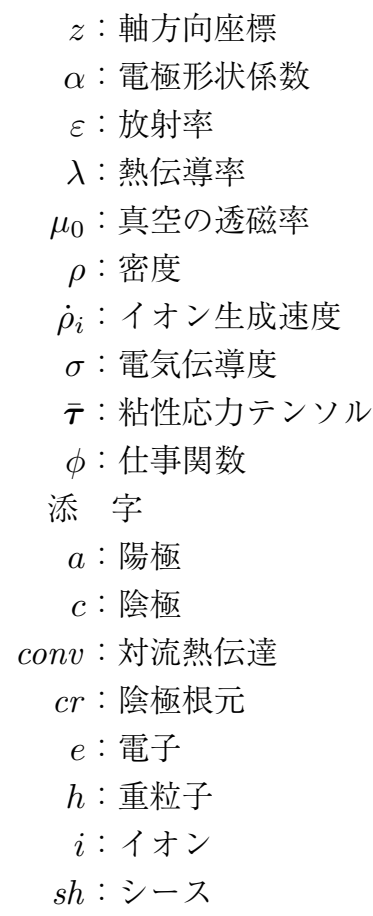

1. はじめに

近年, 小惑星, 火星, 木星水衛星等への探査といった深 宇宙ミッションが数多く検討されている. ペイロード比の 増加とミッション期間の短縮を図るためには, 高い比推力 と高い推力重量比を兼備する電気推進システムの利用が有 効である. 次世代の大型深宇宙ミッションでは, 投入電力 が $100 \mathrm{~kW}$ を超える大電力電気推進システムが求められて いる1,2) が，既存の技術でこれを達成するためには，1 台 当たり $5 \sim 20 \mathrm{~kW}$ で作動する多数のイオンスラスタや Hall 


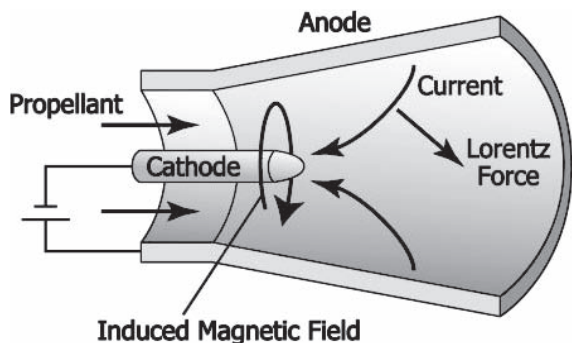

第1図 自己誘起磁場型 MPD スラスタの作動概念

スラスタをクラスタ化する必要があり, システムの複雑化 と重量の増加を招く。これに対して, 本研究で対象とする MPD (Magnetoplasmadynamic) スラス夕は，単体で投入 電力 $100 \mathrm{~kW}$ 超級の作動が可能であることから，次世代の 大型電気推進機として期待されている.

MPD スラスタでは, アーク放電により推進剤を電離す るとともに，それを加速・噴射することで推力を得る ${ }^{3,4}$. MPD スラスタの推力は, 放電による Joule 加熱に起因す る気体力学的推力, ならびに磁場と放電電流の相互作用で ある Lorentz 力に起因する電磁推力からなるが, MPD ス ラス夕を高効率で作動させるためには, 電磁推力を気体力 学的推力に対して十分優位にする必要がある. 第 1 図に示 す自己誘起磁場型 MPD スラス夕（以下単に「MPD スラ ス夕」と記す）の理論的な電磁推力は, Maecker の式5)

$$
F_{E M}=\frac{\mu_{0}}{4 \pi}\left(\ln \frac{r_{a}}{r_{c}}+\alpha\right) J_{d}^{2}
$$

で与えられ，十分な電磁推力を得るためには，陽極/㓌極 半径比 (以下単に「半径比」と呼ぶ) を大きくするととも に, 放電電流を $\mathrm{kA}$ オーダー以上とする必要がある。一方 で，このような大電流放電はスラスタヘッドに大きな熱負 荷を与え, 構成要素各部を極度に高温化させる。このため, $100 \mathrm{~kW}$ 超級の定常作動 MPD スラスタの地上実験では水 冷方式が利用されているが, 実際の宇宙ミッションでは不 向きであり,より簡素・軽量な構成での適切な除熱・放熱の 可否が MPD スラス夕の実用化の鍵となる ${ }^{6}$. しかしなが ら，そのような MPD スラスタは，未だに実現していない。

そこで，本論文では，放射冷却機能を持つ $400 \mathrm{~kW}$ 級定 常作動 MPD スラス夕（推進剤：アルゴン）に対して, 熱 的成立性を考慮した概念設計を試み，プラズマ流れの電磁 流体解析ならびにスラスタヘッドの熱解析から，㓌極半径 及び陰極根元温度をパラメータとして, 熱的制約条件の下 で高い推進効率が得られる設計点を探索し, 同時に設計上 の制限要因とそれらパラメータの影響を明らかにする。

\section{MPD スラスタの構成と熱設計}

2.1 スラスタヘッドの構成要素 MPD スラスタヘッド は, 一般的に, 陽極, 陰極, 陰極ホルダ及び背部絶縁体から 構成され，これらが同軸上に配置される，宇宙空間におい ては，スラス夕内部の熱は最終的に深宇宙への輻射により 排出されなければならず，各電極への熱を放散するための 陽極ラディエータ及び陰極ラディエータが付加される。こ

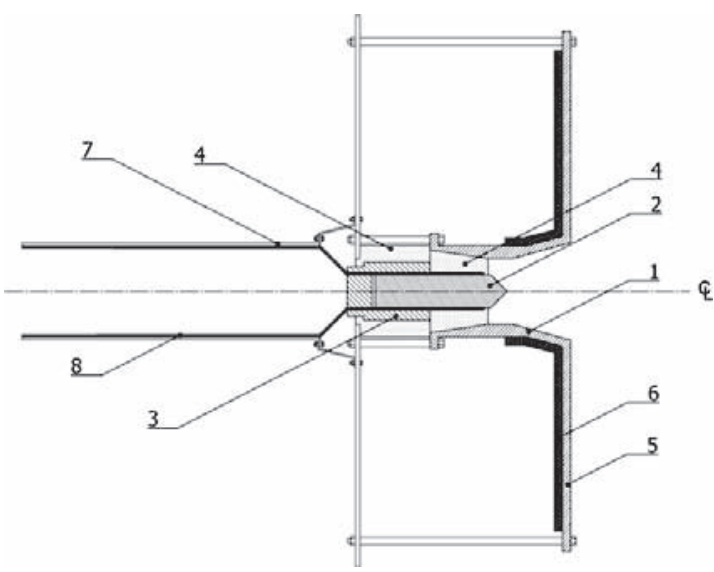

第 2 図 輻射冷却 MPD スラスタヘッドの模式図 1 : 陽極 $(\mathrm{W}), 2$ : 㓌極 $\left(\mathrm{ThO}_{2}-\mathrm{W}\right), 3$ : 㓌極ホルダ $(\mathrm{Mo})$, 4 : 背部絶縁体 $(\mathrm{BN}), 5$ : 陽極ラデイエー夕 $(\mathrm{W}), 6$ : 陽極 ヒートパイプ $(\mathrm{Li} / \mathrm{W}), 7$ : 陰極ラデイエータ $(\mathrm{C} / \mathrm{C}), 8$ : 陰 極除熱デバイス.

のとき, 熱負荷の総量は, 放電に伴う電子の流入出の関倸 から，陰極に比して陽極でより大きくなる7ため，陽極を 外側に，㓌極を内側に配置するのが一般的である。これら の構成要素からなるスラスタヘッドの模式図を第 2 図に示 す。同図では陽極と陽極ラデイエー夕は一体となっている が，放電を担うノズル状の部分を陽極，輻射による放熱を 担う円盤状の部分を陽極ラディエータと区別する。このス ラス夕構成では，放電による陽極内面への熱は，陽極外面 へ伝導し，そこに設置された陽極ヒートパイプを通過して 陽極ラディエータへと輸送される。 また，陰極への熱は，陰 極根元へ伝導し，陰極根元に設置された陰極除熱デバイス を通過して㓌極ラディエータへと輸送される。

なお，MPD スラスタでは，高効率化のために推進剤流 量を小さく設定することから，推進剤を利用する再生冷却 の効果は期待できない，

2.2 陽極 輻射による放熱では，ラディエータの温度が 高いほど必要な面積が小さくなることから, 陽極温度は可 能な限り高いことが要求され, 陽極材料は夕ングステンとし た，陽極の内側半径は，半径比の観点（式 (1) 参照）からは 大きいことが望まれるが, 大き過ぎると推進剤密度の低下か ら放電不安定を招く，そこで, 陽極内側半径は, 推進剂がス ラス夕出口に拈いても典型的な放電電流密度 $\left(10^{6} \mathrm{~A} / \mathrm{m}^{2}\right)$ を電子の熱拡散により賄えるように定めた。

$10 \mathrm{MW} / \mathrm{m}^{2}$ に及ぶ熱流束を受ける陽極の溶融を防ぐた めには，単に陽極ならびに陽極ラディエータからの放射の みでは不十分であり, 更なる除熱の促進が必要となる。そ こで, $10 \mathrm{MW} / \mathrm{m}^{2}$ を超す除熱能力を持つ液体金属ヒート パイプ8)を利用し，大熱量を小温度差で陽極ラディエー夕 へ輸送し，同時に陽極ラディエータの等温化を図ることと した．また，後述するように，陽極内面には局所的に集中 した熱負荷が課されるが，ヒートパイプのドライアウトを 回避するために，陽極厚さを十分大きくし，ヒートパイプ に到達する熱流束の分布を平準化させた。 
陽極ラデイエータ半径は，液体金属ヒートパイプにて最 高で $2000 \mathrm{~K}$ 程度での作動実績がある9) ことから, 数值解 析結果を参照して，ヒートパイプ部分の温度が $2000 \mathrm{~K}$ 以 下となるように試行錯誤的に決定した。

2.3 陰極 陰極材料は, 高融点・低仕事関数を持つトリ ア添加タングステンとした。ただし，トリア枯渴低減の観 点から, 長寿命作動のために $2800 \mathrm{~K}$ を作動温度の上限と する10).

院極では, 先端から根元へと熱伝導のみにより大熱量を 通過させなければならないため, その断面積を十分大きく する（㓌極半径を大きくする）必要があるが, 他方で電磁 推力の観点からは，半径比を大きくする（院極半径を小さ 〈する）必要があることから, 熱的な成立性と高い推進性 能にはトレードオフの関係が存在する。

陰極へも，陽極と同程度の高い熱流束が負荷されること から，根元に㓌極除熱デバイスを設置して除熱を促進する こととした。陰極への熱は陰極内を熱伝導により通過する ため，院極根元温度が低いほど陰極先端温度も低くなり，熱 設計上の余裕が大きくなる。一方で，陰極ラディエータの 面積は, 負荷される熱量と Stefan-Boltzmann 則に基づく 放熱量との平衡で定まることから，㓌極根元温度が低いほ どラディエータ温度も低くなり, 必要な面積が増加する. 陰 極除熱デバイスには, 院極からの除熱と同時に, その熱を 小温度差で離れた位置にある陰極ラデイエータまで輸送す る伝熱促進の機能も必要となるため, 陰極除熱デバイスと しては，陰極根元温度が高い場合には液体金属ヒートパイ プを想定し，陰極根元温度が低い場合には液体金属等を作 動媒体とする流体ループによる熱輸送を想定した。

\section{3. 数値解析モデルと手法}

本研究では, 電磁流体・電極・熱現象をそれぞれモデル 化し, 連携させて解析することで, MPD スラスタの定常 作動状態を模擬した。具体的には, まず, 電磁流体解析に よりプラズマ流れならびに推進性能を評価した上で, 電極 近傍での電流密度, 電子温度から電極モデルにより電極上 の壁面熱流束を算出し, それを熱解析の境界条件として適 用することでスラスタヘッドの温度分布を明らかにした。

3.1 プラズマ流れの電磁流体解析 定常作動時のプラズ マ流れの把握には, 著者らの研究グループで開発したMAPS コード11)を使用した，MAPS コードでは，電磁流体力学 方程式系と一般化された Ohm の式において, 電離非平衡 (電離は 1 価電離のみ考慮) や重粒子と電子の熱的非平衡, Hall 効果, 粘性, 熱伝導等主要な実在気体効果を考慮して おり, 解析結果と実験との良好な一致を確認している ${ }^{12)}$. 同 コードでは, 以下に示す, 質量, イオン質量, 運動量, 重 粒子エネルギー及び電子エネルギーの保存式, ならびに磁 場の誘導方程式を連立して解く.

$$
\begin{aligned}
& \frac{\partial \rho}{\partial t}+\nabla \cdot(\rho \boldsymbol{u})=0 \\
& \frac{\partial \rho_{i}}{\partial t}+\nabla \cdot\left(\rho_{i} \boldsymbol{u}\right)=\dot{\rho}_{i}
\end{aligned}
$$

$$
\begin{aligned}
& \frac{\partial \rho \boldsymbol{u}}{\partial t}+\nabla \cdot(\rho \boldsymbol{u} \boldsymbol{u}+p \overline{\boldsymbol{I}})=\boldsymbol{j} \times \boldsymbol{B}+\nabla \cdot \overline{\boldsymbol{\tau}} \\
& \frac{\partial E_{h}}{\partial t}+\nabla \cdot\left[\left(E_{h}+p\right) \boldsymbol{u}\right] \\
& =p_{e} \nabla \cdot \boldsymbol{u}+\boldsymbol{u} \cdot(\boldsymbol{j} \times \boldsymbol{B}) \\
& +\nabla \cdot\left(\lambda_{h} \nabla T_{h}\right)+\nabla \cdot(\overline{\boldsymbol{\tau}} \boldsymbol{u})+\delta E \\
& \frac{\partial U_{e}}{\partial t}+\nabla \cdot\left(U_{e} \boldsymbol{u}\right) \\
& =-p_{e} \nabla \cdot \boldsymbol{u}+\frac{\boldsymbol{j}^{2}}{\sigma} \\
& +\nabla \cdot\left(\lambda_{e} \nabla T_{e}+\frac{5}{2} \frac{k T_{e}}{e} \boldsymbol{j}\right)-\delta E-\dot{n}_{i} V_{i} \\
& \frac{\partial \boldsymbol{B}}{\partial t}-\nabla \times(\mathbf{u} \times \boldsymbol{B}) \\
& =-\nabla \times\left[\frac{1}{\mu_{0} \sigma} \nabla \times \boldsymbol{B}+\frac{1}{\mu_{0} e n_{e}}(\nabla \times \boldsymbol{B}) \times \boldsymbol{B}\right]
\end{aligned}
$$

ここで，重粒子エネルギー密度と電子エネルギー密度は，

$$
\begin{aligned}
E_{h} & =\frac{1}{2} \rho \boldsymbol{u}^{2}+\frac{3}{2} n_{h} k T_{h} \\
U_{e} & =\frac{3}{2} n_{e} k T_{e}
\end{aligned}
$$

により定義し，電流，圧力に関しては,

$$
\begin{aligned}
& \boldsymbol{j}=\frac{1}{\mu_{0}} \nabla \times \boldsymbol{B} \\
& p=p_{h}+p_{e}=n_{h} k T_{h}+n_{e} k T_{e}
\end{aligned}
$$

とした。 以上の方程式系を, 対流項については 2 次精度 MUSCL タイプ TVD Lax-Friedrichs スキーム ${ }^{13)}$ に基づ き有限体積的に離散化し, 拡散項については 2 次精度中心 差分により離散化した。時間積分には 1 次精度 Euler 陽解 法を用い，時間進行法により定常解を得た。

MAPS コードでは, Debye 長程度となる電極シース領域 は解像できないため, 電極現象は電磁流体解析とは切り離 して取り扱った。すなわち，エネルギー式の電極壁面上に おける境界条件としては, 簡単のために, 電子の流入出に 伴うエネルギーの流入出のみを考慮し, 熱伝達は無視し温 度勾配は無いものとした。

3.2 電極現象 推進効率及び熱負荷の算出に関わる電 極シース電圧は，過去の実験結果 ${ }^{14,15)}$ を参考に陽極で $0 \mathrm{~V}$ を，陰極で $20 \mathrm{~V}$ を仮定した。また，プラズマから電極へ の熱負荷は, 主に放電電流によって決定される10)ことが示 唆されている。本研究では, Stuttgart 大学での定常作動 MPD スラスタの実験結果に基づく半経験式を用いた.

陽極では以下の式10) を用いて壁面熱流束を評価した。

$$
q_{a}=\left(\frac{5}{2} \frac{k T_{e}}{e}+V_{a, s h}+\phi_{a}+V_{a, c o n v}\right) \cdot j_{a}
$$

ここで, 電子温度は電磁流体解析により得られる值を用い, 仕事関数は $4.5 \mathrm{~V}$ (タングステン) とした。対流熱伝達の影 
第 1 表 熱解析の境界条件

\begin{tabular}{lc}
\hline \multicolumn{1}{c}{ 項 目 } & \multicolumn{1}{c}{ 条件 } \\
\hline 陽極への熱負荷 & 式 $(12),(13)$ より \\
陰極への熱負荷 & 得られる壁面熱流束 \\
\hline 陰極根元温度 & $T_{c r}=300 \sim 800 \mathrm{~K}$ \\
\hline 陽極フレア部内面からの輻射 & \\
陽極外面からの輻射 & 材料と温度に \\
陰極先端円錐面からの輻射 & 依存した放射率 \\
背部絶縁体外面からの輻射 & \\
\hline 陽極ラデイエータ下流側表面からの輻射 & \\
\hline
\end{tabular}

響は経験的に $2 \mathrm{~V}$ が用いられている10).

一方，陰極では，以下の式16)を用いて壁面熱流束を評価 した.

$$
q_{c}=c_{c} \cdot j_{c}
$$

彼らの実験では, 直径 $8 \mathrm{~mm}$ のトリア添加タングステン陰 極を用い, 放電電流を $400 \mathrm{~A}$ から $1 \mathrm{kA}$ まで変化させたと ころ, アルゴン雲囲気下のアーク放電に対して 1〜 $5 \mathrm{~W} / \mathrm{A}$ の熱負荷が測定され, 放電電流の増加に伴って単位電流当 たりの熱負荷が減少することが示されている。このことか ら, 㓌極直径を $24 \sim 40 \mathrm{~mm}$, 放電電流を $10 \mathrm{kA}$ とする本研 究では, 熱負荷の係数の下限值 $\left(c_{c}=1 \mathrm{~W} / \mathrm{A}\right)$ を用いた. なお, この熱負荷の係数には, 陰極シース電圧, 陰極周囲 のプラズマからの輻射及び対流熱伝達の影響が陰的に含ま れている.

3.3 スラスタヘッドの熱解析 定常作動時のスラスタ ヘッド温度分布の評価には汎用有限要素法解析ソルバであ るMSC.Nastran ${ }^{17)}$ を用いた。ここでは, 熱伝導率及び放 射率の温度依存性 ${ }^{18)}$ を考慮し，第 1 表のように境界条件を 与えた。 まず, プラズマ流れの電磁流体解析から得られた 壁面熱流束分布を陽極及び陰極にて熱負荷境界条件とした。 その他，深宇宙に露出した境界面については深宇宙（3K） への輻射境界条件を与えた，具体的には，陽極フレア部内 面, 陽極外面, 陰極先端円錐面, 背部絶縁体外面に対して, それぞれの材料の放射率にての輻射境界条件を，陽極ラデイ エータ下流側表面に対して，放射促進のため溶射コーティ ングを施したと仮定して放射率 0.6 にての輻射境界条件を 課した。

本論文で扱う運転条件・スラス夕形状の範囲においては, 陰極（放電室突出部）内での Joule 発熱は, 陰極形状を円 柱で近似し, 電流の側面からの一様な流入を仮定する 0 次 元的な概算で, 最大でも $460 \mathrm{~W}$ 程度であり, 後述する陰極 への合計熱負荷に対して $4.6 \%$ あるることから, 簡単のため 電極内での Joule 発熱は考慮していない.

陽極ヒートパイプは，実効的な熱伝導率 $(28000 \mathrm{~W} / \mathrm{m}$ K）を用いた仮想的な熱の良導体でできた中実棒として取 り扱った。 ヒートパイプの伝熱特性は，一般に蒸発部外壁一 作動蒸気間及び作動蒸気一凝縮部外壁間の熱抵抗により支配 される19)ことから,これらを総括した熱抵抗 ${ }^{19)}$, ならびに 実効的な熱伝導率及びヒートパイプ寸法から定まる中実棒 の熱抵抗が一致するようにした。本研究では, 外径 $10 \mathrm{~mm}$
第 2 表 解析条件

\begin{tabular}{lc}
\hline \multicolumn{1}{c}{ 項 目 } & 条件 \\
\hline 推進剂種 & $\mathrm{Ar}$ \\
放電電流 $J_{d}, \mathrm{kA}$ & 10 \\
推進剂質量流量 $\dot{m}, \mathrm{~g} / \mathrm{s}$ & 1.8 \\
推進剂スラスタ入口温度, $\mathrm{K}$ & 1,000 \\
陽極シース電圧 $V_{a, s h}, \mathrm{~V}$ & 0 \\
陰極シース電圧 $V_{c, s h}, \mathrm{~V}$ & 20 \\
\hline
\end{tabular}

第3表 スラスタ寸法

\begin{tabular}{cc}
\hline \multicolumn{1}{c}{ 項 目 } & 值 \\
\hline 陽極内側半径 (入口), $\mathrm{mm}$ & 40 \\
陽極内側半径 (出口), $\mathrm{mm}$ & 59 \\
陽極長さ, mm & 100 \\
一円筒部長さ, mm & 30 \\
—フレア部長さ, mm & 70 \\
陽極壁厚さ (円筒部), mm & 15 \\
陽極壁厚さ (フレア部), mm & 10 \\
陰極半径, mm & $12 \sim 20$ \\
陰極長さ, mm & 23 \\
㓌極半頂角, deg & 45 \\
陽極ラディエータ半径, $\mathrm{mm}$ & 290 \\
\hline
\end{tabular}

の棒状ヒートパイプ（総括熱抵抗は $6.3 \times 10^{-3} \mathrm{~K} / \mathrm{W}$ ）を 30 本，陽極外面から陽極ラディエー夕上流側表面にわたり 等間隔で放射状に配置することを想定したが，この状況を 2 次元軸対称解析で模擬するために, 方位角方向で平均化 を施した。

また，陰極除熱デバイスは，実際には解析せずに，それ が接している㓌極根元部分に温度一定の温度境界条件を与 えることにより，その作動を模擬した。

3.4 解析条件とスラスタ寸法 解析条件を第 2 表に示 す. 本研究では, 電磁推力が十分優位となる作動条件とし て，放電電流を $10 \mathrm{kA}$ とし，その放電電流がおおよそ理論 臨界電流 ${ }^{20)}$ となるように推進剤質量流量を $1.8 \mathrm{~g} / \mathrm{s}$ とした. また，陰極根元温度を $300 ８ 00 \mathrm{~K}$ の間で $100 \mathrm{~K}$ ごとに変 化させて解析を行った。

2 節で述べた事項を考慮し, 本研究では第 3 表に示す寸 法のスラスタについて検討した。半径比は推進性能を特徴 付ける最も重要な形状パラメータであることから, 本解析 では，熱的な成立性と高い推進性能を両立させる陰極半径 を探索するために，陽極寸法を一定とし，陰極半径を 12 $20 \mathrm{~mm}$ の間で $2 \mathrm{~mm}$ ごとに変化させて解析を行った。陽極 寸法一定の下での陰極半径の減少は, 半径比の増加に対応 する，㓌極ラディエータ面積は，陰極根元温度をラディエー 夕温度と等しいとして概算すると, 陰極根元温度に応じて, $T_{c r}=300 \mathrm{~K}$ では $30 \mathrm{~m}^{2}, T_{c r}=800 \mathrm{~K}$ では $0.5 \mathrm{~m}^{2}$ となる.

\section{4. 解 析 結 果}

4.1 推進性能とプラズマ流れ 第 3 図に推力の半径比依 存性を示す. 陰極半径の減少, 半径比の増加により, 気体力 学的推力がほとんど変化しない一方で, 電磁推力は増加し, 結果として合計推力は増加する。これは Maecker の式から 予測されるとおりの結果であり，㓌極径を減少させること 


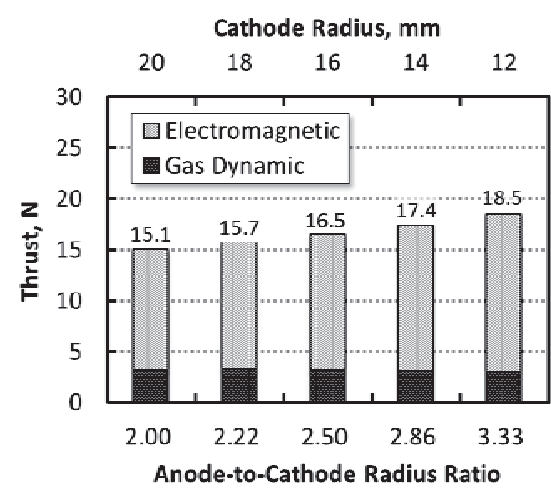

第 3 図 推力の半径比依存性 $\left(\mathrm{Ar}, J_{d}=10 \mathrm{kA}, \dot{m}=1.8 \mathrm{~g} / \mathrm{s}\right)$

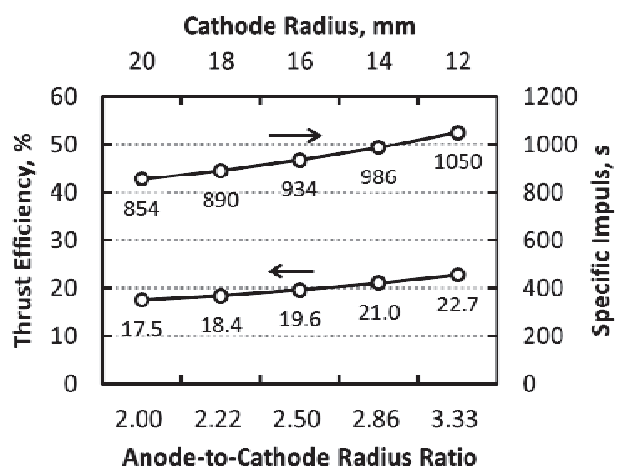

第 4 図 推進効率及び比推力の半径比依存性 $(\mathrm{Ar}, 10 \mathrm{kA}, 1.8 \mathrm{~g} / \mathrm{s})$

で陰極側面近傍での磁場が強まりここれによって Lorentz 力が増加することによる.

第 4 図に推進性能の半径比依存性を示す．比推力及び推 進効率も, 半径比の増加に伴って向上する.

第 5 図に陰極半径が $20 \mathrm{~mm}$ (上側）と $12 \mathrm{~mm}$ （下側）の 場合の放電電流経路と Hall パラメー夕を示す. 半径比が 大きい（半径 $12 \mathrm{~mm}$ ）場合には, 放電電流経路は全体とし て下流側に張り出し, 陽極上ではスラス夕出口側に偏るこ とが分かる。これは, Hall 効果の顕著化に起因するもので ある. すなわち, 半径比の増加に従い, 除極近傍の磁場が 強まり，その結果として Lorentz力による放電室内での加 速及びプラズマの中心軸上へのピンチが促されることで, 陽極近傍の推進剂密度が低下寸る。これにより，陽極近傍 $(z=30 \sim 100 \mathrm{~mm}, r=-40 \sim-60$ 付近) での Hall パラ メータが増加し, Hall 効果による放電電流経路の張り出し が顕著になる。

4.2 電極への熱負荷 式 (2), (3) に従い, 電磁流体解 析により得られた電極上での電流密度分布, 陽極壁面近傍 での電子温度分布に基づいて, 陽極及び陰極への熱流束分 布を評価した．陰極半径が $20 \mathrm{~mm}$ と $12 \mathrm{~mm}$ の場合の陽極 上壁面熱流束分布を第 6 図に示す。まず陽極については, 陰極寸法にかかわらず, 出口端 $(z=100 \mathrm{~mm}$ 付近) 及び 中腹部 $(z=30 \mathrm{~mm}$ 付近) に熱負荷の集中がみられる. 半 径比を増加させると, 先に述べたように電流分布が出口側 に偏ることから, 熱負荷も入口側で小さく, 出口側で大き くなる.

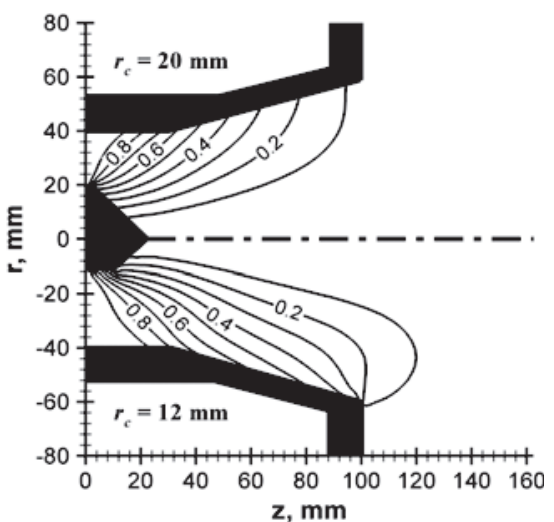

(a) 放電電流経路（ラベルはそれより下流を流れる電流の割合）

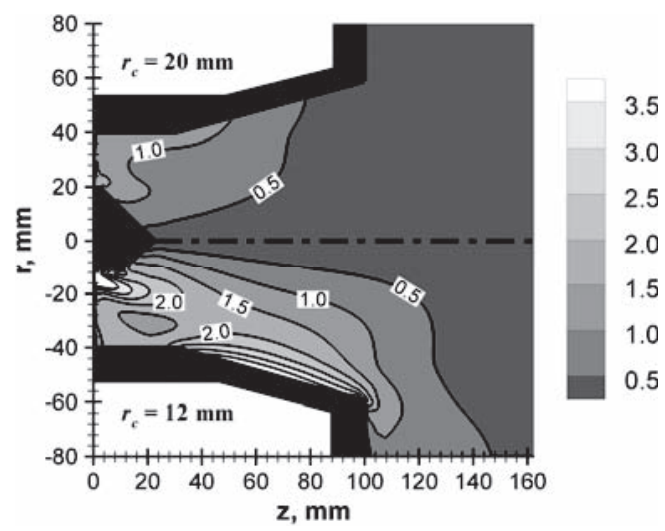

(b) Hall パラメータ

第 5 図 電磁流体解析により得られたプラズマ流れ場 $\left(\mathrm{Ar}, J_{d}=10 \mathrm{kA}\right.$, $\dot{m}=1.8 \mathrm{~g} / \mathrm{s}$ )

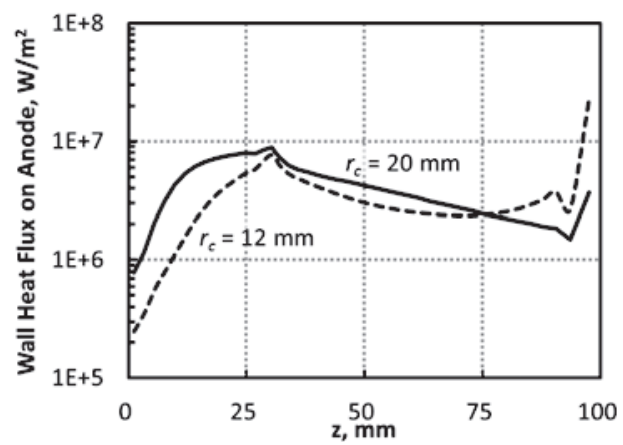

第 6 図 陽極上壁面熱流束 $\left(\mathrm{Ar}, J_{d}=10 \mathrm{kA}, \dot{m}=1.8 \mathrm{~g} / \mathrm{s}\right)$

同様に，半径が $20 \mathrm{~mm}$ と $12 \mathrm{~mm}$ の場合の陰極上壁面熱 流束分布を第 7 図に示す，陰極については，寸法にかかわら ず，熱流束は，円柱部の側面 $\left(r_{c}=20 \mathrm{~mm}\right.$ の場合は $z=0$ $\sim 3 \mathrm{~mm}, r_{c}=12 \mathrm{~mm}$ の場合は $\left.z=0 \sim 11 \mathrm{~mm}\right)$ で比較的 大きく, 先端の円錐部では円柱部よりも熱流束は小さくな るが, 先端に向けて緩やかに熱流束が増加する。半径比を 増加させた $r_{c}=12 \mathrm{~mm}$ の場合には, 陰極表面積が減少す るため, 特に先端の円錐部で熱流束が上昇する。

第 8 図に投入電力及び電極熱負荷の半径比依存性を示す. 陽極及び陰極への合計熱負荷は，それぞれ $120 \sim 140 \mathrm{~kW}$ 及 び $10 \mathrm{~kW}$ であり，これらは投入電力に対して，それぞれ約 $30 \%$ 及び約 $3 \%$ でる。半径比を増加させると，陽極出口 


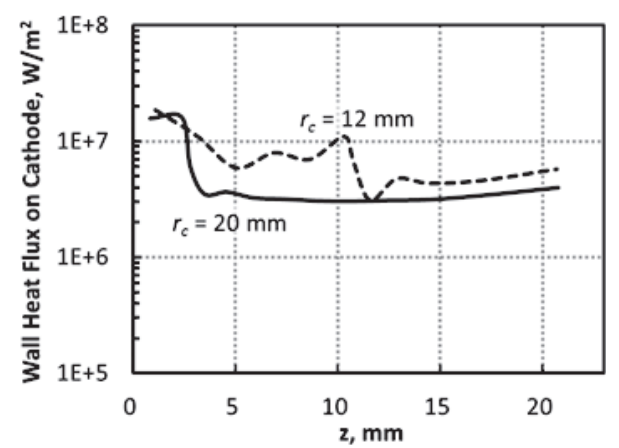

第 7 図 陰極上壁面熱流束 $\left(\mathrm{Ar}, J_{d}=10 \mathrm{kA}, \dot{m}=1.8 \mathrm{~g} / \mathrm{s}\right)$

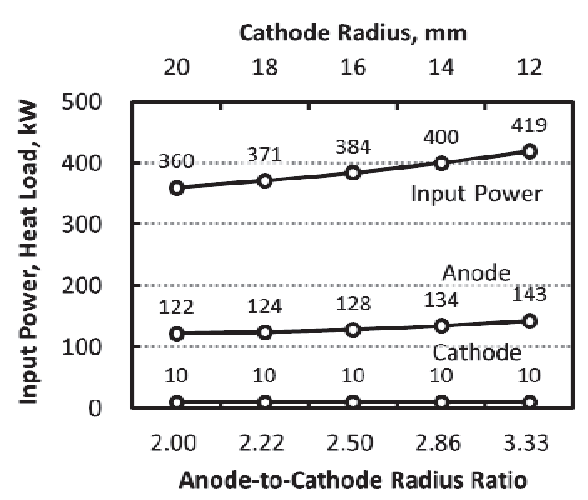

第 8 図 投入電力及び電極熱負荷の半径比依存性 $(\mathrm{Ar}, 10 \mathrm{kA}, 1.8 \mathrm{~g} / \mathrm{s})$

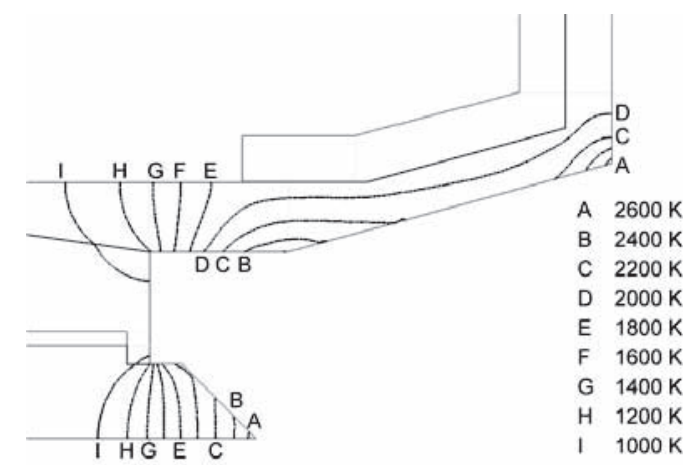

第 9 図 放電室近傍のスラス夕温度分布 $\left(\mathrm{Ar}, J_{d}=10 \mathrm{kA}\right.$, $\left.\dot{m}=1.8 \mathrm{~g} / \mathrm{s}, r_{c}=16 \mathrm{~mm}, T_{c r}=800 \mathrm{~K}\right)$

端での電流集中が顕著化すること, 及び電流経路の伸長に 伴う Joule 加熱量が増加することから, 陽極近傍での電子 温度が上昇し，陽極への合計熱負荷は増加する。

4.3 スラスタ温度分布 第 9 図にスラス夕熱解析の典 型例として, 院極半径 $16 \mathrm{~mm}$, 陰極根元温度 $800 \mathrm{~K}$ とし た場合のスラス夕温度分布を示す。眓から明らかなように, 陽極出口端，陽極中腹部及び陰極先端が高温となっている. 陽極出口端及び陽極中腹部の高温化は, 熱負荷集中（第 6 図参照）を反映したものである。また陰極先端の高温化は, 除熱を根元で行っていることによる.

第 10 図にスラス夕各部の温度の半径比依存性を示す。陽 極では, 半径比を増加させると, 熱負荷分布が全体として スラスタ出口側に偏ることから, 陽極中腹部での高温化は

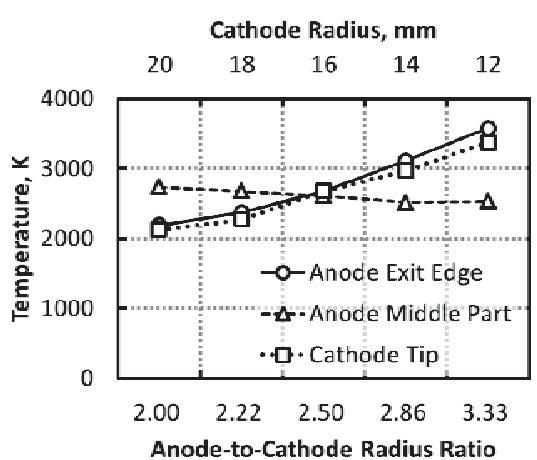

第 10 図 スラスタ各部の温度の半径比依存性 $\left(\mathrm{Ar}, J_{d}=10 \mathrm{kA}\right.$, $\dot{m}=1.8 \mathrm{~g} / \mathrm{s}, T_{c r}=800 \mathrm{~K}$ )

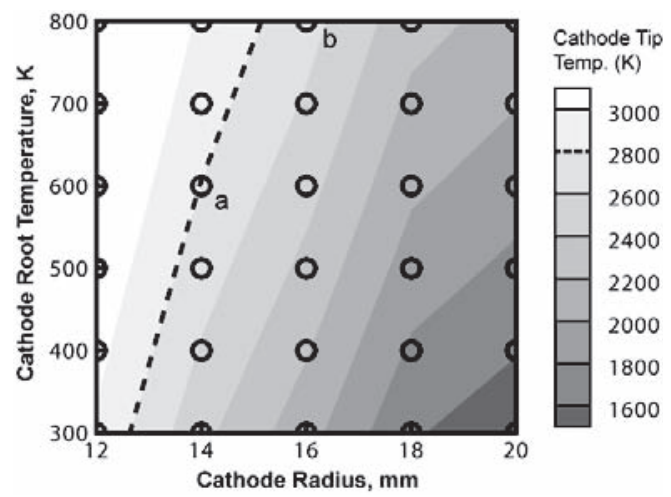

第 11 図 陰極先端温度 $(\mathrm{K})$ の陰極半径及び院極根元温度依存性 $(\mathrm{Ar}$, $\left.J_{d}=10 \mathrm{kA}, \dot{m}=1.8 \mathrm{~g} / \mathrm{s}\right)$

印 : 解析点, 破線 : 陰極作動温度上限の推奖值 $(2800 \mathrm{~K})$.

緩和する一方で，陽極出口端の高温化がより顕著になる。ま た，陰極では，半径比を増加させると，全体として壁面熱 流束が上昇すること, 及び, 陰極断面積の減少により軸方 向根元側への熱通過が低下することから，㓌極先端の高温 化が顕著となる。

陰極先端温度の陰極半径及び陰極根元温度依存性を第 11 図に示す。第 3 図及び第 4 図に示したとおり，陰極半径が 小さい (半径比が大きい) ほど推進性能は高い. また陰極 根元温度が高いほど必要な陰極ラディエータ面積は小さく なるので，推進性能及びスラス夕重量の観点からは，第 11 図の左上の条件ほど望ましい。一方で，そのとき陰極先端 温度はより上昇し, 破線よりも左上の領域では陰極寿命の 観点から推奨される作動上限温度 $2800 \mathrm{~K}$ を超過する。 こ のことから，同図の破線上の条件が熱的制約下での限界条 件となる。

本研究における解析点の中では, 陰極半径 $14 \mathrm{~mm}$ (半径 比 2.86) ・陰極根元温度 $600 \mathrm{~K}$ とした場合（第 11 図 a 点） や陰極半径 $16 \mathrm{~mm}$ (半径比 2.50 ) - 陰極根元温度 $800 \mathrm{~K}$ と した場合（第 11 図 b 点）が破線に近い。それらの場合, 陰 極先端温度はそれぞれ $2800 \mathrm{~K}, 2680 \mathrm{~K}$ であり院極作動温 度上限の推奨值を超過せず，また，陽極出口端温度はそれ ぞれ $3100 \mathrm{~K}, 2680 \mathrm{~K}$ でありタングステンの融点約 $3670 \mathrm{~K}$ を十分下回っているので, 熱的制約条件を満足した設計点 
であると言える。

以上のように，陰極半径を適切に定め, かつ, 陽極及び 陰極においてヒートパイプ等の伝熱促進デバイスを用いて 除熱を促進することで, 良好な推進性能を維持しつつ電極 溶融の生じない大電力スラス夕が実現可能であることが示 唆された。ただし, 陽極出口端, 陽極中腹及び陰極先端で 高温化が見られたことから, 熱設計の観点からの制限要因 となり得る。

本研究で用いた電極熱負荷モデルは, Stuttgart 大学で の定常作動実験に則したものであり，妥当性の高いモデル である。しかしながら, 本研究で検討した運転条件・スラ ス夕形状は, Stuttgart大学で行われていたものと同一で はないため, 今後, 要素試験を通しての電磁流体・電極・ 熱現象のモデルの精緻化を図り，それらを連成させてより 確度の高い予測, 評価を行うことが課題となる。

$$
\text { 5. おわりに }
$$

投入電力 $400 \mathrm{~kW}$ 級の定常作動自己誘起磁場型アルゴン MPD スラスタに対して, プラズマ流れの電磁流体解析と スラスタヘッドの熱解析を連携して行い, 推進性能及びス ラス夕温度分布の陰極半径及び陰極根元温度依存性を検討 した。これにより以下の結論を得た。

(1) $400 \mathrm{~kW}$ 級の投入電力においても, 陰極半径を適切に 定め, かつ単なる熱伝導・輻射によるだけではなく, ヒート パイプ等によって電極からの除熱を促進することにより, 電 極溶融の生じないスラスタが実現可能であることを示した.

（2）熱的成立性を担保する制約下では, 推力 $17 \mathrm{~N}$, 比推 力 $990 \mathrm{~s}$, 推進効率 $21 \%$ が達成可能であると予測された.

（3）スラス夕温度は, 特に陽極出口端, 陽極中腹及び陰 極先端で高温化し, 熱設計に際して, これらの部分の温度 が寸法決定の制限要因となる.

（4）陰極半径を減少させると, 電磁推力の増加により推 進性能は向上するものの, 一方で Hall 効果に起因する陽極 出口端への電流集中の顕著化, ならびに陰極の熱通過の低 下によって, 陽極出口端及び陰極先端で温度が上昇し, 熱 的な余裕が低下する.

\section{参 考 文 献}

1) Casaregola, C., Cesaretti, G. and Andrenucci, M.: HiPER: a Roadmap for Future Space Exploration with Innovative Electric Propulsion Technologies, 31st International Electric Propulsion Conference, University of Michigan, Ann Arbor, Michigan, IEPC Paper 09-066, 2009.

2) Sankaran, K., Cassady, L., Kodys, A. D. and Choueiri, E. Y.: A Survey of Propulsion Options for Cargo and Piloted
Missions to Mars, Ann. N.Y. Acad. Sci., 1017 (2004), pp. 450-467.

3) 栗木恭一, 荒川義博: 電気推進ロケット入門, 東京大学出版会, 東京, 2003 .

4) Jahn, R. G.: Physics of Electric Propulsion, McGraw-Hill, New York, 1968.

5) Maecker, H.: Plasmaströmungen in Lichtbögen Infolge eigenmagnetischer Kompression, Z. Phys., 141 (1955), pp. 198216 (in German).

6) Sercel, J. C. and Krauthamer, S.: Multimegawatt Nuclear Electric Propulsion; First Order System Design and Performance Evaluation, AIAA Space Systems Technology Conference, San Diego, California, AIAA Paper 86-1202, 1986.

7) Shin, K. T. and Pfender, E.: Electrode Energy Transfer Mechanisms in a MPD Arc, AIAA J., 8 (1970), pp. 211-215.

8) Rosenfeld, J. H. and North, M. T.: Porous Media Heat Exchanger for Cooling of High-Power Optical Components, Optical Eng., 34 (1995), pp. 335-341.

9) Ernst, D. M. and Eastman, G. Y.: High Temperature Heat Pipe Technology at Thermacore-An Overview, AIAA 20th Thermophysics Conference, Williamsburg, Virginia, AIAA Paper 85-0981, 1985.

10) Bruno, C.: Nuclear Space Power and Propulsion Systems, AIAA, Reston, Virginia, 2008.

11）窪田健一, 佐藤博紀, 船木一幸, 奥野喜裕：MPD スラス夕の電 磁流体数值シミュレーション (特集: 電気推進·先端推進の数值シ ミュレーション), 日本航空宇宙学会誌, 59 (2011), pp. 396-401.

12) Kubota, K., Funaki, I. and Okuno, Y.: Comparison of Simulated Plasma Flow Field in a Two-Dimensional Magnetoplasmadynamic Thruster with Experimental Data, IEEE Trans. Plasma Sci., 37 (2009), pp. 2390-2398.

13) Tóth, G. and Odstrčil, D.: Comparison of Some Flux Corrected Transport and Total Variation Diminishing Numerical Schemes for Hydrodynamic and Magnetohydrodynamic Problems, J. Comput. Phys., 128 (1996), pp. 82-100.

14) Auweter-Kurtz, M., Kurtz, H., Merke, W., Schrade, H., Sleziona, C. and Wegmann, T.: High Power Steady State MPD Thrusters, IRS-90-P4, Final Report, Grant US AFOSR-88-0325, Institut für Raumfahrtsysteme, Universität Stuttgart, 1990.

15) Nakata, D., Toki, K., Funaki, I., Shimizu, Y., Kuninaka, H. and Arakawa, Y.: Experimental Measurement of Total Sheath Fall Voltage in an MPD Thruster, 44th AIAA/ASME/SAE/ASEE Joint Propulsion Conference \& Exhibit, Hartford, Connecticut, AIAA Paper 2008-4635, 2008

16) Hügel, H. and Krülle, G.: Phänomenologie und Energiebilanz von Lichtbogenkathoden bei niedrigen Drucken und Hohen Stromstärken, Beiträge aus der Plasmaphysik, 9 (1969), pp. 87-116 (in German).

17) MSC.Software: MD Nastran \& MSC Nastran 2011 Quick Reference Guide, www.mscsoftware.com, 2011.

18) Touloukian, Y. S.: Thermophysical Properties of High Temperature Solid Materials, Macmillan, New York, 1967.

19) Reay, D. A. and Kew, P. A.: Heat Pipes, ButterworthHeinemann, Oxford, 2006.

20) Yoshikawa, T., Kagaya, Y. and Kuriki, K.: Thrust and Efficiency of the K-III MPD Thruster, J. Spacecraft, 21 (1984), pp. $481-487$. 